\title{
Review
}

\section{Foucault and the politics of rights}

\author{
Ben Golder \\ Stanford University Press, Stanford, 2015, 304 pp., \\ ISBN-13: 978-0804796491
}

Contemporary Political Theory (2017) 16, 313-316. doi:10.1057/s41296-016-0016-8; advance online publication 23 August 2016

Michel Foucault, a political actor and rights advocate? Making claims for the right to die, the rights of the governed, and rights to sexuality? This is a most unfamiliar Foucault for many, but it is the focus of Ben Golder's Foucault and the Politics of Rights. Breathing new life into somewhat stale debates about the political character of Foucault's work, Golder reveals a thinker and activist deeply committed to rights politics as well as to critiques of power and subjectivity. He shows us how Foucault can offer a scathing critique of the tenets of liberalism on which rights politics are said to rest and yet embrace the rights politics of the Polish solidarity movement, the Iranian revolution, and prison reform efforts. Indeed, in Golder's capable hands and lucid prose, Foucault's turn to rights in his later life no longer appears as a repudiation of his earlier insights about the insidiousness of disciplinary power and the biopolitical regimes in which such power is exercised nor a startlingly naïve act of political capitulation. It becomes a powerful act of resistance. With this provocative account, Golder's work certainly deepens our understanding of Foucault's ideas in important ways. But so too does it shed light on the ongoing value of rights for contemporary politics, shaking up both the liberal faith in and the postmodern skepticism of rights in the process.

At the heart of Golder's argument about the meaning and implications of Foucault's rights politics is the notion of "critical counter-conduct." It is the lens through which he reads Foucault's late writings and activism and the main subject of the first substantive chapter of the book. Against those who understand critique as the rejection or dismissal of an idea, Golder explains that for Foucault genealogical critique involves the historicizing of an idea, discourse, or political practice such that a different future is made possible. Genealogy is the "exposure of the contingency of our present" that is also the exposure of "the possibility of thinking, acting, and doing...otherwise" (p. 36). And "counter-conduct," the phrase Foucault uses to capture what happens when concepts and practices of the day are taken up in ways that challenge dominant forms of power, is but one example of doing otherwise made possible by critique. Counter-conduct is a practice through which, in Foucault's words, dominant power is "redistribute[d],

(c) 2016 Macmillan Publishers Ltd. 1470-8914 Contemporary Political Theory Vol. 16, 2, 313-316 www.palgrave.com/journals 
reverse[d], nullif[ied], and partially or totally discredit[ed]" (p. 55). Such was the case when asceticism, mysticism, and eschatology deployed aspects of pastoral power against pastoralism itself. And, as the rest of Golder's book sets out to prove, such is the case with Foucault's rights discourse.

In Chapter Two, Golder turns his focus specifically to the subject of rights, the human of human rights, the individual of individual liberty. He questions the claim that Foucault's turn to rights marks a radical shift in his thinking and a disconcerting embrace of liberal individualism. Golder details the claims Foucault made about individuals' right to speak out against governments, to be protected from the abuse of government power, and to intervene in international affairs, as found in his writings on the Iranian revolution, the Polish Solidarity movement, and international piracy projects. This writing, Golder acknowledges, especially when coupled with Foucault's late work on the care of the self, appears to suggest a return to a sovereign subject capable of autonomy and self-authorization. But appearances can be deceiving. To read Foucault as having embraced "a doer behind the deed" (p. 70) would be, Golder argues, to miss the way in which Foucault's rights claims are themselves part of a critical counter-conduct.

Indeed, read through the lens of critical counter-conduct, Foucault's rights claims become performative rather than representational, constitutive and contestatory rather than declarative and finalizing. Rights claiming, Golder shows us, is not a practice through which a sovereign individual, untainted by politics and power, articulates a universal truth about human rights in an effort to limit state power. It is a practice through which the very subject of rights is constituted and reimagined. As Foucault explained himself, "It is not because there are laws, and not because I have rights, that I am entitled to defend myself; it is because I defend myself that my rights exist and the law respects me....A right is nothing unless it comes to life in the defence which occasions its invocation" (p. 80).

In Chapter Three, Golder shifts the focus from those who read the late Foucault as a new liberal to those who emphasize his critical perspective on rights. How to respond to those who believe that rights remain an occasion for enhancing the regulatory power of the state and entrenching individuals in particularized identity categories? For that, Golder turns to Foucault's engagement in the politics of sexuality, particularly the gay rights movement. Continuing lines of argument begun earlier, Golder emphasizes the performative character of rights claims to suggest that sexuality rights are not simply statements of universal truths. They are practices that contest conventional ways of thinking about who we are, whom we should love, and how we should use our bodies. Foucault's advocacy for the right of adult adoption provides a good example. While the claim seems to be about limiting the power of the state to control the lives of individuals, it is actually a critique of the dominant norms of relationships and practices of care. As Golder explains, to speak of sexual choice and liberty as Foucault does is not to imagine a sphere of life into which the government or power never encroaches, but to challenge the ways of living we take to be natural, normal, and inevitable. 
To his credit, Golder does not shy away from acknowledging that rights claims like these are often "sites of regulatory control" (p. 92) that reinforce problematic identity categories. But he is adamant that this is never all that they are or do. Just as "rights are the occasion and the vehicle of a disciplinary inscription of homosexual identity, they also emerge, ambivalently, as the scene of that inscription's potential loosening, overcoming, or displacement" (p. 106). Like all rights claims, sexuality rights are never simply emancipatory or regulating; their outcomes not reducible to what happens in the courtroom or with respect to the reach of state policy. The contemporary implications of such an interpretation of Foucauldian sexuality rights are clear, though implicit. It reminds us that the fight for LGBTQ equality does not end with a marriage equality courtroom victory nor is it wholly undermined by romanticizations of love and monogamy. From the Foucauldian perspective with which Golder provides us, we can see that marriage rights claims may domesticate and yet reveal the contingency of conceptions of marriage and families that make their future revision all the more possible.

In Chapter Four, Golder's final substantive chapter, he explores another aspect of the ambivalence at the heart of Foucault's politics of rights; not the ambivalence of rights themselves, but Foucault's own ambivalence about their potential. Here Golder turns to Foucault's tactical and strategical choice-making about when and why to invoke (or not) the language of rights in the context of death. Golder reminds us that Foucault defended the right to die in the context of debates about controlling one's death by suicide but eschewed rights claims in the context of death penalty politics. From Foucault's perspective, a claim about the right to life would never adequately address what was at stake in death penalty cases. Golder's point here is, I believe, to make visible that Foucault, the critic of rights, was alive and well in Foucault, the rights advocate.

In this chapter, as in his earlier ones, Golder's ability to explain and then clear away misconceptions and confusions about Foucault's key ideas proves exceptional, and the evidence he mounts to show us the continuities between his early and late work is extensive. All the more striking is that these arguments unfold without rancor or ridicule. Golder acknowledges that interpretations of Foucault as a born-again liberal or as providing an unequivocal critique of rights are "perfectly plausible" (p. 31). He appreciates how puzzling it might seem that someone so dismissive of the idea of a subject "naturally" endowed with anything, let alone inalienable rights, could become involved in human rights activism or that one so critical of the idea that power is located in the state and capable of being limited by the law would take up a juridical discourse as a tool of resistance. And yet, Golder shows us again and again that Foucault's rights politics is a logical expression and telling illustration of Foucault's philosophical and political commitment to permanent provocation.

Where Golder's book may leave the reader wanting more is in its evidence of the efficacy of rights. Foucault's rights politics, Golder argues, opens up the

(c) 2016 Macmillan Publishers Ltd. 1470-8914 Contemporary Political Theory Vol. 16, 2, 313-316 315 
opportunity to think more deeply about the very specific ways in which "rights can function to contest and remake relations of power" (p. 6). But Golder's attention, like a number scholars interested in rethinking the political character of rights, myself included, is directed more towards the philosophical than the quotidian. This leaves a somewhat vague picture of how exactly the "tactical reappropriation, reinvestment, and reimagining" of rights displaces and destabilizes (p. 50). Persuading readers that he is correct about Foucault is one thing; persuading them that Foucault is correct about rights is another. To that end, I think it would have been helpful if Golder had been more explicit about how rights claiming engenders shifts in conduct, attitudes, and patterns of behavior, if he had provided more detail about how such practices change the very conditions of misery, abuse, and inhumanity that motivate their use in the first place.

My point here is that if we take up rights in order to address injustices or inequities in the world, and if we want to assess their utility or understand their political potential, we need to identify with care the effects their invocation has on more than our thinking. At the same time, we need to explore and appreciate the manner in which those effects come to be. Shifts in conduct (and the institutional practices and policies as well as power/knowledge networks in which this conduct occurs) come about not upon a single iteration of a rights claim nor through spoken or written words alone. Rights-claiming that destabilizes and displaces, that remakes relations of power and forms of subjectivity, is the result of ongoing political engagement at a variety of levels often entailing a multiplicity of political strategies. Indeed, the very intelligibility and subsequent legality of something like same-sex spousal relationships and marriage rights, for example, are the result of actions and utterances repeated over time, utterances that both draw on and transform the normative context in which they are made. This repetition, and the ongoing, often mundane, and continually changing practices of political engagement, I would argue, are as much a part of a politics of rights as the shifts in thinking and speaking that Foucault's rights politics enact and enable.

Karen Zivi

Grand Valley State University, Allendale, MI 49401, USA zivik@gvsu.edu 